\title{
Anti-CD123 ADC IMGN632
}

National Cancer Institute

\section{Source}

National Cancer Institute. Anti-CD123 ADC IMGN632. NCI Thesaurus. Code C143251.

An antibody-drug conjug ate (ADC) consisting of a humanized anti-CD123 (interleukin-3 (IL-3) receptor alpha chain; IL3RA) immunog lobulin G1 (IgG1) monoclonal antibody conjug ated, via a cleavable linker, to a cytotoxic, DNA-alkylating payload, which is an indolino-benzodiazepine dimer containing an imine moiety, with potential antineoplastic activity. Upon administration of anti-CD123 ADC IMGN632, the antibody moiety targets the cell surface antigen CD123. Upon antibody/antigen binding, internalization, and lysosome uptake, the cytotoxic moiety is released, and covalently binds to and alkylates DNA with its imine moiety. This results in cell cycle arrest in S-phase, which leads to apoptosis and inhibition of cell growth in cells overexpressing CD123. CD123, the alpha subunit of the IL-3 receptor, regulates the proliferation, survival and differentiation of hematopoietic cells. CD123 is overexpressed on a variety of cancers. 